$\mathrm{Xi}$ and other Chinese leaders see science as a central element in building bridges with other countries and Bai Chunli, president of CAS, emphasized that point last year in the Bulletin of the Chinese Academy of Sciences (CAS Bulletin). "Science, technology and innovation are the core driving force for the BRI development," he wrote.

For the past six months, Nature has been travelling to countries participating in the BRI. From Beijing to Islamabad, Colombo to Nairobi to Lima, we are exploring in a series of five articles over the next two weeks how China is transforming the world of science. China's universities - along with a vast network of CAS institutes - are fanning out across the globe. They are offering scientific assistance and signing collaborative agreements on a scale not seen since the United States and the former Soviet Union vied with each other to fund researchers in allied nations during the cold war. On 19 April, Bai announced that CAS has invested more than 1.8 billion yuan (almost US\$268 million) in science and technology projects as part of the BRI.

In Sri Lanka, China is co-funding a centre focused on safe drinking water and supporting investigations into a kidney-disease crisis in the country's rural population. In Pakistan, it is co-sponsoring a range of research centres that are studying topics from rice agriculture to artificial intelligence and railway engineering. In the heart of the European Union, a Chinese-Belgian science park provides homes for companies trying to expand trade in medical devices, solar power and other technologies. And in South America, China has partnered with Chile and Argentina on astronomical centres and has gained access to some of the best observatories in the world. In total, the scientific side of the BRI involves tens of thousands of researchers and students, and hundreds of universities. There are few regions of the developing world where China's scientific outreach does not have a footprint.

This marks a profound shift in where low- and middle-income countries are drawing scientific support - a sphere in which China is emerging as a competitor to the United States, Japan and the wealthier European nations. And as China rises as a science-development superpower, it brings a different perspective from those of other leading science nations.

First, there is the concept of win-win that pervades all BRI projects, says Theresa Fallon, director of the Centre for Russia Europe Asia Studies in Brussels. Every major investment brings benefits not only to the host country but also to China, which is hoping to gain both scientifically and economically from the ventures. Another difference is that China sees itself as a more appropriate partner for poorer nations because it still recalls what it was like to be poor, says Li Yin, deputy director of CAS's international cooperation department in Beijing.

China's approach through the BRI has earned it many fans in countries where it has invested, including Sri Lanka's President Maithripala Sirisena and Pakistan's Prime Minister Imran Khan. Khan said in his victory speech last year that he's keen to learn how China went from being a poor country to an emerging superpower.

But there's another view of China's scientific rise - the narrative that low- and middle-income countries are sleepwalking into the arms of an authoritarian and neocolonial state, and that everything else, including technology agreements and research alliances, are part of that trajectory. In this narrative, struggling nations are sagging under billions of dollars of debt to China and are giving away the keys to untold amounts of economically valuable and sensitive resources - from oceanic-current readings to biological samples to next-generation communication systems. Another concern is that China is only now beginning to acknowledge the environmental harm that BRI projects could cause as they pave routes through ecologically fragile habitats in Pakistan's northern mountains and other regions, and dam up rivers across southeast Asia and South America.

From a science perspective, the overall goal of the BRI is clear to restore China's place as one of the world's great civilizations, and that includes being seen by all other nations as a source of scientific power, too. But Christopher Cullen, a historian of Chinese science at the Needham Institute in Cambridge, UK, says it is too early to say how China's dealings with other countries will evolve.

\section{MANY PATHS}

For well over 2,000 years, the silk roads linked the Far East to Europe, and Chinese leaders have been invoking the rhetoric of reviving these ancient trade routes since the early 2000s. But when Xi became China's president in 2013, he made this goal a priority as he launched the BRI with fanfare and ancient proverbs. "The sea is big because it admits all rivers," he said during launch events in Indonesia and Kazakhstan.

The sea is even bigger than Xi's plans originally indicated. Over the past six years, the BRI has grown to incorporate a complex, global network of ocean and overland routes, with China as the focal point. The full scope of the BRI is impossible to judge, because China's government has never released a list of all the projects that are in the works or planned. But estimates of its size cover a wide range from $\$ 1$ trillion to $\$ 8$ trillion.

As one component of this massive initiative, China is creating what it calls a 21st Century Maritime Silk Road, a giant oceanic loop that links the country's shipping to the nations bordering each of the great oceans, including some in Africa and South America. Then there's the Silk Road Economic Belt, a complicated network of six overland corridors that connect China to some of Asia and Europe's major cities through railways, roads and maritime paths.

The signs of a scientific BRI emerged soon after Xi visited central Asia in September 2013. The following year, CAS funded an upgrade to a 1-metre telescope at Uzbekistan's Ulugh Beg Astronomical Institute. The improvement paved the way for the Uzbekistan institute to survey the northern sky in collaboration with China's Xinjiang Astronomical Observatory. Uzbekistan has no experience in telescope making, observatory director Shuhrat Ehgamberdiev told the CAS Bulletin, so the most important technological part was done by China's engineers. This was the beginning of much grander plans by CAS.

The BRI's scientific component is being masterminded by Bai. Trained in China as an X-ray crystallographer, Bai worked with John Baldeschwieler at the California Institute of Technology in Pasadena in the mid-1980s on scanning tunnelling microscopy.

Even early in Bai's career, it was clear he would go far, says Baldeschwieler, who remembers predicting that Bai would one day become president of CAS. During a visit to Beijing in 1995, Baldeschwieler was amazed to find that Bai had arranged a meeting with China's then-president Jiang Zemin. "We were picked up in a small bus and taken by police escort with flashing lights through Tiananmen Square to the Great Hall of the People." Young boys and girls were lining the stairs on a red carpet, he recalls.

Under Bai, the science BRI has been running on three parallel tracks. In China, CAS has established five centres of excellence at its institutes, and these host the $200 \mathrm{PhD}$ students that the academy trains every year.

Outside China, it has opened nine research and training centres, in Africa, central Asia, South America and south and southeast Asia often co-funded by their host countries. The China-Brazil Joint Laboratory for Space Weather in São José dos Campos, for example, is monitoring space weather changes and developing forecast models. In Bangkok, the CAS Innovation Cooperation Center helps Thailand's universities and technology companies to work with Chinese counterparts, and at the same time gives China a foothold in the region. And then there are hundreds of individual collaborations between CAS and universities in China and elsewhere.

The third track is what CAS is calling the Digital Belt and Road, a platform for participating countries to share the data obtained as part of their collaborative projects with each other and with China. These data include satellite images as well as quantitative data on natural hazards, 


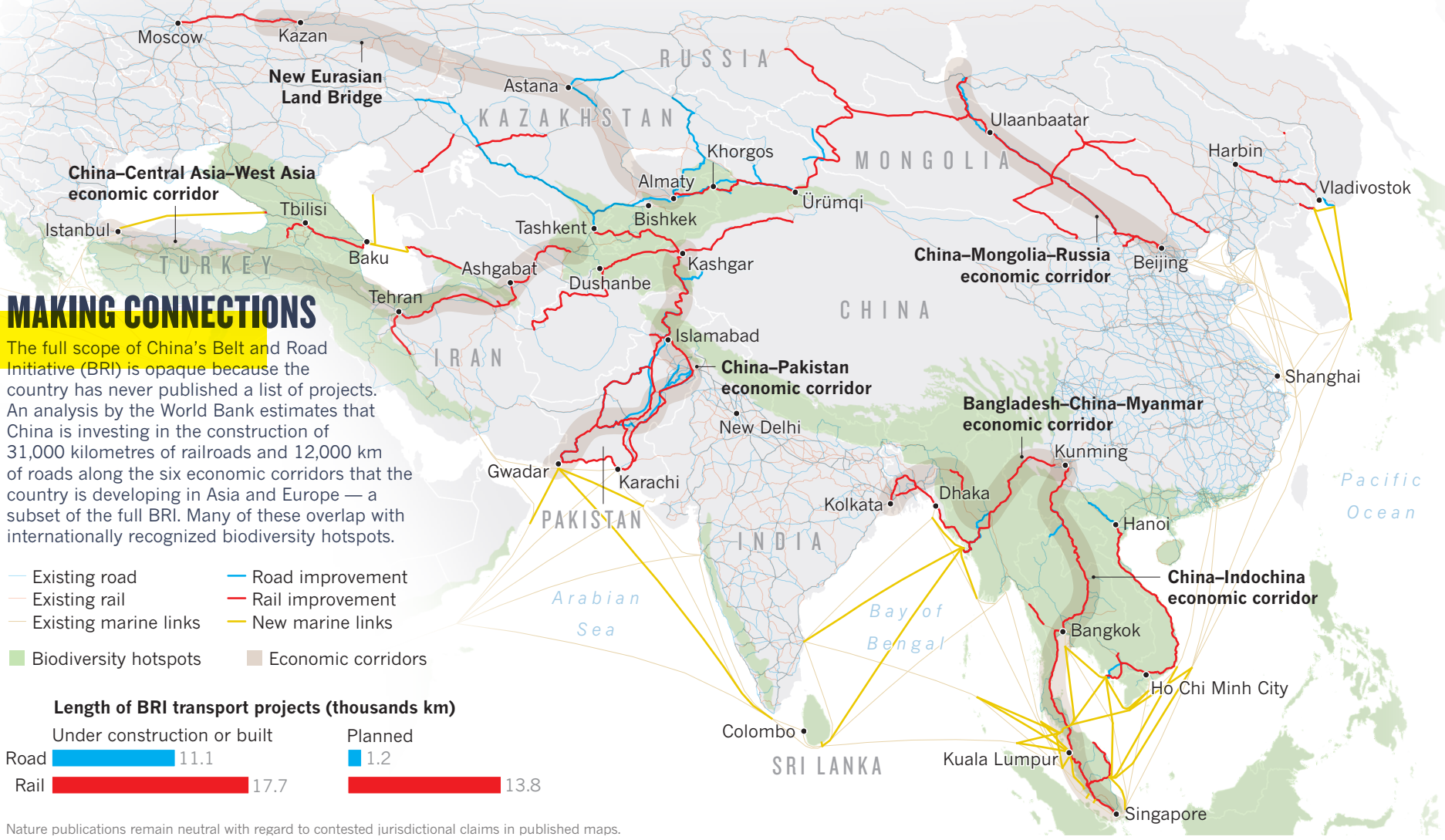

water resources and cultural heritage sites.

To draw these and other activities together, CAS established a super committee of scientific research organizations in 2016. This network goes by the acronym ANSO, short for Alliance of International Science Organizations in the Belt and Road Region. Its 37 members span the globe, stretching from the Russian Academy of Sciences to the University of Chile. The United Nations Educational, Scientific and Cultural Organization in Paris is also a founding member. As part of its activities, ANSO plans to support and organize research in BRI countries on sustainable development, including improving food security and reducing water scarcity.

\section{TROUBLE SPOTS}

As the infrastructure projects take off and China increases its scientific activities overseas, concerns are starting to emerge over how it is carrying out its work.

Much of the criticism comes from countries not currently involved in the BRI. India's government, for example, is angry that it has not been consulted about activities taking place in what it regards as its backyard, and more than once has warned Sri Lanka's policymakers to scale back the extent of their scientific cooperation with China.

Another potential flashpoint is how China is building the information-technology infrastructure for the Digital Belt and Road. The United States and some other countries have warned in particular about signing agreements with Chinese telecommunications giant Huawei to build the next generation $5 \mathrm{G}$ mobile communications network. They say that this potentially gives the Chinese government surveillance opportunities, because Huawei is also providing BRI countries with surveillance tools — including facial recognition technology. Huawei, however, strenuously denies that it has installed access routes in its equipment for unauthorized users, such as might be used by the Chinese government.

One of the strongest concerns in BRI countries is about the environmental impacts of the projects, which are transforming the landscape in dozens of nations. The conservation group WWF reports that the main BRI connections between Asia and Europe cross through 1,739 areas that have been identified as important for biodiversity conservation, affecting 265 threatened species, including 81 endangered species such as the saiga antelope (Saiga tatarica), tigers (Panthera tigris) and giant pandas (Ailuropoda melanoleuca).

One project that has environmentalists worried is a planned 350-kilometre, \$3.8-billion Hungary-to-Serbia railway. This has also attracted the attention of EU authorities and is still awaiting regulatory approval. In addition, China has not ratified the Espoo Convention, which requires member states to assess the environmental and health impacts of development projects at an early stage.

Pervez Hoodbhoy, a physicist at Forman Christian College in Lahore, Pakistan, says that few - if any - of China's scientific collaborations are evaluating the environmental impacts of BRI infrastructure projects. "There's a real lack of research on a regulatory framework for the BRI projects themselves and this leads to the rest of us having to make guesses as to what is happening and what the impacts might be," he says. "There needs to be research on these questions, too," says Hoodbhoy. "Without environmental safeguards in place, there are risks of exacerbating environmental problems, putting pressure on dwindling natural resources and displacing communities," agrees Aban Marker Kabraji, Asia director at the International Union for Conservation of Nature (IUCN) in Bangkok.

One obstacle to environmental due diligence, says Qi Ye, director of the Brookings-Tsinghua Center for Public Policy in Beijing, is that institutions in both China and BRI countries are reluctant to do anything that could slow construction. Chinese companies, he says, are often "operating in an environment where the local government or contracting party needs or wants quick results". Strategic environmental impact assessments take time to do properly, and can result in changes to original specifications - all of which can lead to projects being delayed. "That is not a popular option," says Qi.

Another problem is that contracts can state that environmental impact assessments are the responsibility of the host country. But because poor countries often have little monitoring or evaluation capacity for such assessments, construction projects sometimes go ahead without proper scrutiny, environmental advocates say.

There are signs that China is starting to address such concerns. China's own conservation research organizations, such as the Dunhuang Academy, and environmental scientists including Ma Keping 
